\title{
Effect of prolonging radiation delivery time on retention of gammaH2AX
}

\author{
Vitali Moiseenko ${ }^{1}$, Judit P Banáth ${ }^{2}$, Cheryl Duzenli ${ }^{1}$ and Peggy L Olive*2
}

Address: ${ }^{1}$ Medical Physics Department, British Columbia Cancer Agency, Vancouver, Canada and ${ }^{2}$ Medical Biophysics Department, British Columbia Cancer Research Centre, Vancouver, Canada

Email: Vitali Moiseenko - vmoiseenko@bccancer.bc.ca; Judit P Banáth - jbanath@bccrc.ca; Cheryl Duzenli - cduzenli@bccancer.bc.ca; Peggy L Olive* - polive@bccrc.ca

* Corresponding author

Published: 27 June 2008

Radiation Oncology 2008, 3:18 doi:10.1186/1748-717X-3-18

This article is available from: http://www.ro-journal.com/content/3/1/18

(C) 2008 Moiseenko et al; licensee BioMed Central Ltd.

This is an Open Access article distributed under the terms of the Creative Commons Attribution License (http://creativecommons.org/licenses/by/2.0), which permits unrestricted use, distribution, and reproduction in any medium, provided the original work is properly cited.
Received: 20 February 2008

Accepted: 27 June 2008

\begin{abstract}
Background and purpose: Compared to conventional external beam radiotherapy, IMRT requires significantly more time to deliver the dose. Prolonging dose delivery potentially increases DNA repair which would reduce the biological effect. We questioned whether retention of $\gamma \mathrm{H} 2 \mathrm{AX}$, a measure of lack of repair of DNA damage, would decrease when dose delivery was protracted.
\end{abstract}

Materials and methods: Exponentially growing $\mathrm{SiHa}$ cervical carinoma cells were irradiated with $6 \mathrm{MV}$ photons in a water tank using a VarianEX linear accelerator. Cells held at $37^{\circ} \mathrm{C}$ received 2 $\mathrm{Gy}$ in $0.5 \mathrm{~min}$ and $4 \mathrm{~Gy}$ in I min. To evaluate effect of dose delivery prolongation, 2 and $4 \mathrm{~Gy}$ were delivered in 30 and $60 \mathrm{~min}$. After $24 \mathrm{~h}$ recovery, cells were analyzed for clonogenic survival and for residual $\gamma \mathrm{H} 2 \mathrm{AX}$ as measured using flow cytometry.

Results: Increasing the dose delivery time from 0.5 or I min to 30 or 60 min produced a signficant increase in cell survival from 0.45 to 0.48 after $2 \mathrm{~Gy}$, and from 0.17 to 0.20 after $4 \mathrm{~Gy}$. Expression of residual $\gamma \mathrm{H} 2 \mathrm{AX}$ decreased from I.27 to I.22 relative to background after $2 \mathrm{~Gy}$ and I.46 to I.39 relative to background after $4 \mathrm{~Gy}$, but differences were not statistically significant. The relative differences in the slopes of residual $\gamma \mathrm{H} 2 \mathrm{AX}$ versus dose for acute versus prolonged irradiation bordered on significant $(p=0.055)$, and the magnitude of the change was consistent with the observed increase in surviving fraction.

Conclusion: These results support the concept that DNA repair underlies the increase in survival observed when dose delivery is prolonged. They also help to establish the limits of sensitivity of residual $\gamma \mathrm{H} 2 \mathrm{AX}$, as measured using flow cytometry, for detecting differences in response to irradiation.

\section{Background}

Intensity modulated radiation therapy (IMRT) is being adopted in radiotherapy centers world-wide with the goal of improving beam conformation to the tumor while minimizing damage to surrounding normal tissues. How- ever, IMRT treatments require longer dose delivery times leading to the concern that less tumor cell kill will occur as a result of repair during treatment $[1,2]$. Experiments from several groups have demonstrated small but often 
significant increases in cell survival when dose delivery is protracted over 10-30 min [3-6].

The increase in cell survival by protraction of dose has been associated with the capacity of cells to repair DNA damage; one of the earliest papers reported a reduction in chromsome aberration frequency when the X-ray dose was delivered in $1 \mathrm{~min}$ versus $16 \mathrm{~min}$ [7]. Therefore, IMRT should be less effective because fewer lethal DNA lesions are produced for the same total dose [8]. While experimental evidence using survival is convincing, a direct measure of DNA repair provides insights into the effect of dose delivery prolongation in IMRT and conditions under which this prolongation would be detrimental for radiation therapy outcome.

DNA double-strand breaks are generally accepted to be the most important potentially lethal lesions produced by ionizing radiation. A method for the sensitive detection of individual double-strand breaks is based on measurement of a specific phosphorylation on a nucleosomal histone, $\mathrm{H} 2 \mathrm{AX}$, that occurs rapidly at the site of each double-strand break [9]. Antibody labeling of the phosphorylated form of H2AX (called $\gamma \mathrm{H} 2 \mathrm{AX}$ ) together with flow cytometry provides a rapid and objective method of quantifying this molecule after irradiation [10]. In contrast to other DNA damage assays (e.g., pulsed-field gel electrophoresis or comet assay), $\gamma \mathrm{H} 2 \mathrm{AX}$ can be used to detect double-strand breaks at therapeutic doses. The fraction of tumor cells that retain $\gamma \mathrm{H} 2 \mathrm{AX}$ foci $24 \mathrm{~h}$ after X-irradiation has been correlated with the fraction of cells that survive to form a colony $[11,12]$. The question we wished to address is whether flow cytometry analysis of residual $\gamma \mathrm{H} 2 \mathrm{AX}$ would be sufficiently sensitive and robust to detect the relatively small increase in surviving fraction after protracted radiation exposures. We chose to examine SiHa cervical carcinoma cells since this cell line showed a significant increase in surviving fraction using an IMRT protocol [5]. Preliminary experiments using continuous low dose rate versus acute exposure to X-rays [13] provided the rationale for developing a protocol to simulate an IMRT dose delivery rate using a linear accelerator. The overall dose delivery time was longer than is typical for IMRT, but the major goal was to employ a simple and well defined dose delivery method to test the ability of $\gamma \mathrm{H} 2 \mathrm{AX}$ to serve as a surrogate of cell killing.

\section{Methods}

\section{Cell source and maintenance}

SiHa human cervical cancer cells were obtained from American Type Culture Collection and maintained in minimal essential medium (MEM) containing 10\% fetal bovine serum (FBS). Exponentially growing cells were seeded overnight in $90 \mathrm{~mm}$ dishes and trypsinized just before each experiment using $0.1 \%$ trypsin in citrate saline buffer. Single cells were resuspended in $5 \mathrm{ml}$ MEM $+10 \%$ FBS at a density of $2 \times 10^{5}$ cells $/ \mathrm{ml}$ in Falcon polycarbonate tubes. Six tubes were prepared for each exposure condition and transferred to a water bath at $37^{\circ} \mathrm{C}$.

\section{Irradiation}

Tubes were submersed and irradiated in a water tank at $37^{\circ} \mathrm{C}$ as an array of six with $6 \mathrm{MV}$ photons using Varian EX linear accelerator. Irradiation conditions were: sourceaxis distance $100 \mathrm{~cm}$, depth $5 \mathrm{~cm}$, field size $20 \times 20 \mathrm{~cm}^{2}$. Tubes were placed within a $10 \mathrm{~cm}$ region, $10 \mathrm{~cm}$ from the tube midline to the bottom of the tank for backscatter. The photon beam was calibrated according to the TG51 protocol; output variations through the time period spanning measurements were within $0.3 \%$ according to monthly quality assurance. Irradiations were performed at a rate of $400 \mathrm{MU} / \mathrm{min}$, with acute doses of 2 and $4 \mathrm{~Gy}$ delivered in 0.5 and $1 \mathrm{~min}$. For protracted delivery, 16 equal segments were delivered with 2 and 4 min intervals between the segments for the 30 and 60 min deliveries, respectively. Splitting the total dose into multiple small doses as a surrogate for IMRT was previously used by Ogino et al. [14]. Although only one fractionation schedule was examined here, this was considered adequate to determine whether $\gamma \mathrm{H} 2 \mathrm{AX}$ could be a useful surrogate for cell clonogenic response.

\section{Clonogenic survival assay}

After exposure, cells were plated in $60 \mathrm{~mm}$ tissue culture dishes and allowed to recover for $24 \mathrm{~h}$ while attached to plates. This delay in plating was necessary so that the response of the same cell population could be compared for retention of $\gamma \mathrm{H} 2 \mathrm{AX}$ and survival. After recovery, cells were trypsinized and counted with a Coulter Counter. A portion of the cells was plated at a density of 500-2500 cells in duplicate using $90 \mathrm{~mm}$ dishes. Plates were stained and colonies were counted two weeks later. Counts from the two plates were averaged, and surviving fraction was calculated as the ratio of the plating efficiency of the treated cells divided by the plating efficiency of the control cells $(0.68 \pm 0.02)$. Experiments were repeated $2-4$ times giving results for 12-24 irradiated tubes. From each experiment, the remaining cells were fixed in $70 \%$ ethanol for measurement of residual $\gamma \mathrm{H} 2 \mathrm{AX}$.

\section{Measurement of $\mathrm{\gamma H} 2 \mathrm{AX}$ by flow cytometry}

Ethanol-fixed samples were rehydrated in Tris-buffered saline and incubated for 2 hours with anti- $\gamma \mathrm{H} 2 \mathrm{AX}$ mouse monoclonal antibody (Upstate or Abcam, 1:500 dilution). Samples were washed by centrifugation and resuspended for one hour in secondary Alexa- 488 conjugated goat anti-mouse IgG (Molecular Probes, 1:200). After a second rinse, cells were resuspended in $1 \mu \mathrm{g} / \mathrm{ml} \mathrm{ml} \mathrm{4',6-}$ diamidino-2-phenylindole dihydrochloride hydrate (DAPI; Sigma) to stain DNA. Analysis was conducted 
using a dual-laser Coulter Elite cell sorter [15]. Samples were gated based on forward and peripheral light scatter, and 10,000 cells were analyzed. To correct for differences in DNA content, FITC fluorescence intensity was divided by DAPI fluorescence intensity for each cell. Relative $\gamma \mathrm{H} 2 \mathrm{AX}$ fluorescence was then determined by dividing the mean fluorescence of the irradiated samples by the mean fluorescence of the control samples, averaged for the 3-6 control samples per individual experiment. Two to 4 experiments were conducted per dose and data were pooled.

\section{Statistical analysis}

ANOVA was used to determine the significance of the difference between variation for inter-experiment versus intra-experiment measurements. Analysis of co-variance was used to examine the significance of the difference between the slopes of the $\gamma \mathrm{H} 2 \mathrm{AX}$ dose response curves for acute versus protracted irradiations.

\section{Results and discussion}

Clonogenic surviving fraction was measured for SiHa cells exposed to 2 or 4 Gy given either within 1 min or using an protocol that protracted dose delivery over 30 or $60 \mathrm{~min}$. No difference in clonogenic survival was observed between the responses of cells exposed using the 30 or 60 min protocols so those results were pooled. The lack of a difference between 30 and $60 \mathrm{~min}$ is not unexpected because the dose per fraction is small enough to ensure that the alpha term dominates the response. Prolonging the dose delivery resulted in a significant increase in clongenic surviving fraction for SiHa cells (Fig. 1a; Table 1). Although differences in effects of dose protraction are known to be cell line dependent [5], the extent of recovery
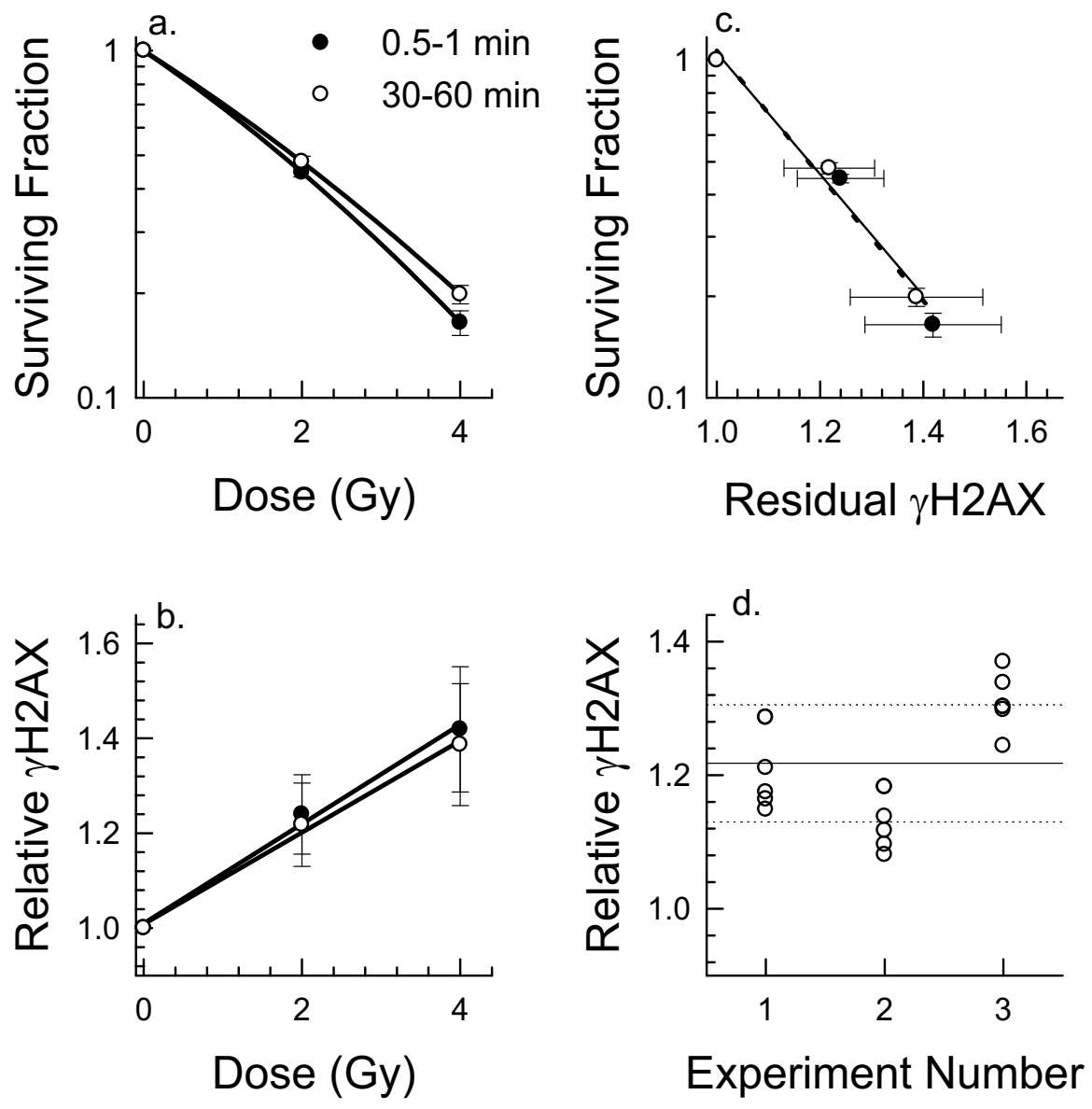

Figure I

Comparison between surviving fraction and relative retention of $\gamma \mathrm{H} 2 \mathrm{AX}$ for SiHa cells exposed to 2 or $4 \mathrm{~Gy}$ over 0.5 or I min or protracted over 30 or $\mathbf{6 0}$ min. Panel a: Clonogenic surviving fraction (mean \pm SD). Panel b: Residual $\gamma \mathrm{H} 2 \mathrm{AX}$ relative to unirradiated cells (mean \pm SD). Panel c: Comparison between results in panel a and b. Linear best fits are shown for the acute and protracted exposures. Panel d: Relative $\gamma \mathrm{H} 2 \mathrm{AX}$ calculated for 3 independent experiments of 6 samples when SiHa cells were exposed to $2 \mathrm{~Gy}$ using the protracted protocol. Mean \pm SD for the pooled samples is indicated by the lines. The F value is 18.95 indicating significant inter-experimental differences. 
Table I: Clonogenic survival and $\gamma \mathrm{H} 2 \mathrm{AX}$ retention for $\mathrm{SiHa}$ cells after acute or protracted exposures

\begin{tabular}{|c|c|c|c|}
\hline Dose & $\begin{array}{l}\text { Integral Exposure Time } \\
\text { (min) }\end{array}$ & $\begin{array}{l}\text { Surviving Fraction } \\
\text { (number of samples) }\end{array}$ & $\begin{array}{l}\text { Residual } \gamma \mathbf{H} 2 \mathbf{A X} \mathbf{X}^{\mathrm{b}} \\
\text { (number of samples) }\end{array}$ \\
\hline 2 Gy acute & 0.5 & $0.446 \pm 0.013(12)$ & $1.265 \pm 0.089(12)$ \\
\hline 2 Gy protracted & 30 and 60 & $0.478 \pm 0.018(18)^{*}$ & $1.218 \pm 0.087(18)$ \\
\hline 4 Gy acute & 1 & $0.164 \pm 0.014(18)$ & $1.46 \mid \pm 0.142(12)$ \\
\hline 4 Gy protracted & 30 and 60 & $0.199 \pm 0.012(24)^{*}$ & $1.387 \pm 0.128(18)$ \\
\hline
\end{tabular}

\footnotetext{
a Mean and standard deviation for clonogenic surviving fraction expressed relative to the unirradiated control cells. Cells were plated for survival 24 $\mathrm{h}$ after irradiation.

* Result significantly different relative to the response of cells exposed in $\leq \mathrm{I}$ min.

b Mean and standard deviation for $\gamma \mathrm{H} 2 \mathrm{AX}$ expression measured $24 \mathrm{~h}$ after irradiation and expressed relative to the unirradiated cells.
}

seen for SiHa cells is within the range of values reported for 7 cell lines [3-6]. Pooling results from these 4 studies, the average increase in surviving fraction for a 2 Gy exposure protracted over $10-30$ min was $17 \pm 12 \%$. Our results indicate a relative increase of $7.2 \%$ when 2 Gy was protracted over 30-60 min. A larger increase might have been observed had cells been plated immediately. The dose deficit over a course of 30 fractions is calculated to be $5.6 \mathrm{~Gy}$, or 3 fractions, even for this small increase.

When cells from the same exposed population were fixed, stained for $\gamma \mathrm{H} 2 \mathrm{AX}$, and analyzed by flow cytometry, more residual $\gamma \mathrm{H} 2 \mathrm{AX}$ was observed after acute than protracted exposure (Table 1). Differences between the averages for individual doses were not significant although analysis of the slopes of the two dose response curves in Fig. 1b yeilded a borderline p-value of 0.055 . The slope for the acute exposure curve was $8 \%$ higher than the slope for protracted delivery, consistent with the observed survival difference. When survival and residual $\gamma \mathrm{H} 2 \mathrm{AX}$ were directly compared, the slope was the same for cells exposed acutely to 2 or 4 Gy versus cells given the protracted exposure (Fig. 1c). This result supports the hypothesis that prolonging dose delivery results in reduction of lethal DNA damage and this underlies the increase in cell survival.

Sources of variability in our measurement of $\gamma \mathrm{H} 2 \mathrm{AX}$ were largely the result of inter-experimental variability (Fig. 1d). Some of this variability arose from differences in antibody source although normalizing results for each set of experiments did not result in statistically significant differences between the groups. Variation was also associated with daily differences in flow cytometer set-up and alignment. In previous experiments that examined residual $\gamma \mathrm{H} 2 \mathrm{AX}$ in human lymphocytes $24 \mathrm{~h}$ after $2.7 \mathrm{~Gy}$, ethanolfixed samples were stored so that samples from 40 patients could be stained and analyzed on the same day [10]. Although this is recommended practice when small differences in response are expected, it is not always practical.

\section{Conclusion}

Results presented here help to define the lower limit of sensitivity of $\gamma \mathrm{H} 2 \mathrm{AX}$ for detecting differences in response to radiation using flow cytometry. Differences of $5 \%$ or more in surviving fraction for the acute and protracted protocols are likely to be required to detect a significant difference in retention of $\gamma \mathrm{H} 2 \mathrm{AX}$. Under the less than ideal conditions for this study, the extent of reduction in residual $\gamma \mathrm{H} 2 \mathrm{AX}$ was consistent with the measured increase in survival. These results support models that explain dose protraction based on DNA repair that occurs during treatment, and they contribute to the increasing experimental evidence indicating that dose correction is advisable when fraction delivery time is increased. Future experiments that examine different fractionation schedules, response of DNA repair deficient cell lines, and behavior of cells in vivo should be informative.

\section{Competing interests}

The authors declare that they have no competing interests.

\section{Authors' contributions}

VM conceived the idea and VM, CD and PO designed the experiments, VM and CD performed the irradiations, JB prepared the cells and performed the measurements of $\gamma \mathrm{H} 2 \mathrm{AX}, \mathrm{PO}$ analyzed the data and drafted the manuscript with the help of VM and JB. All authors read and approved the final manuscript.

\section{Acknowledgements}

This study was supported by a grant from the Canadian Cancer Society.

\section{References}

I. Fowler JF, Welsh JS, Howard SP: Loss of biological effect in prolonged fraction delivery. Int J Radiat Oncol Biol Phys 2004, 59:242-249.

2. Wang JZ, Li XA, D'Souza WD, Stewart RD: Impact of prolonged fraction delivery times on tumor control: a note of caution for intensity-modulated radiation therapy (IMRT). Int J Radiat Oncol Biol Phys 2003, 57:543-552.

3. Sterzing F, Munter MW, Schafer M, Haering P, Rhein B, Thilmann C, Debus J: Radiobiological investigation of dose-rate effects in intensity-modulated radiation therapy. Strahlenther Onkol 2005, | 81:42-48.

4. Mu X, Lofroth PO, Karlsson M, Zackrisson B: The effect of fraction time in intensity modulated radiotherapy: theoretical and 
experimental evaluation of an optimisation problem. Radiother Oncol 2003, 68:18I-I87.

5. Moiseenko V, Duzenli C, Durand RE: In vitro study of cell survival following dynamic MLC intensity-modulated radiation therapy dose delivery. Med Phys 2007, 34: I5I 4-1520.

6. Zheng XK, Chen LH, Yan X, Wang HM: Impact of prolonged fraction dose-delivery time modeling intensity-modulated radiation therapy on hepatocellular carcinoma cell killing. World J Gastroenterol 2005, I I: |452-I456.

7. Sax K: The Time Factor in X-Ray Production of Chromosome Aberrations. Proc Natl Acad Sci U S A 1939, 25:225-233.

8. Curtis SB: Lethal and potentially lethal lesions induced by radiation--a unified repair model. Radiat Res 1986, 106:252-270.

9. Rogakou EP, Boon C, Redon C, Bonner WM: Megabase chromatin domains involved in DNA double-strand breaks In vivo. J Cell Biol 1999, 146:905-916.

10. Olive PL, Banath JP, Keyes M: Residual gammaH2AX after irradiation of human lymphocytes and monocytes in vitro and its relation to late effects after prostate brachytherapy. Radiother Oncol 2008, 86:336-346.

II. Klokov D, Macphail SM, Banath JP, Byrne JP, Olive PL: Phosphorylated histone $H 2 A X$ in relation to cell survival in tumor cells and xenografts exposed to single and fractionated doses of X-rays. Radiother Oncol 2006, 80:223-229.

12. Banath JP, MacPhail SH, Olive PL: Radiation sensitivity, H2AX phosphorylation, and kinetics of repair of DNA strand breaks in irradiated cervical cancer cell lines. Cancer Res 2004, 64:7|44-7| 49

13. Moiseenko V, Banath JP, Olive PL, Duzenli C: Preliminary study of the effect of prolonged radiation delivery times in IMRT on retention of gammaH2AX. Med Phys 2007, 34:2484.

14. Ogino $H$, Shibamoto $Y$, Sugie $C$, Ito M: Biological effects of intermittent radiation in cultured tumor cells: influence of fraction number and dose per fraction. J Radiat Res (Tokyo) 2005, 46:40I-406.

15. Durand RE: Calibration of flow cytometer detector systems. Methods Cell Biol 1994, 42 Pt B:597-604.
Publish with Biomed Central and every scientist can read your work free of charge

"BioMed Central will be the most significant development for disseminating the results of biomedical research in our lifetime. "

Sir Paul Nurse, Cancer Research UK

Your research papers will be:

- available free of charge to the entire biomedical community

- peer reviewed and published immediately upon acceptance

- cited in PubMed and archived on PubMed Central

- yours - you keep the copyright 